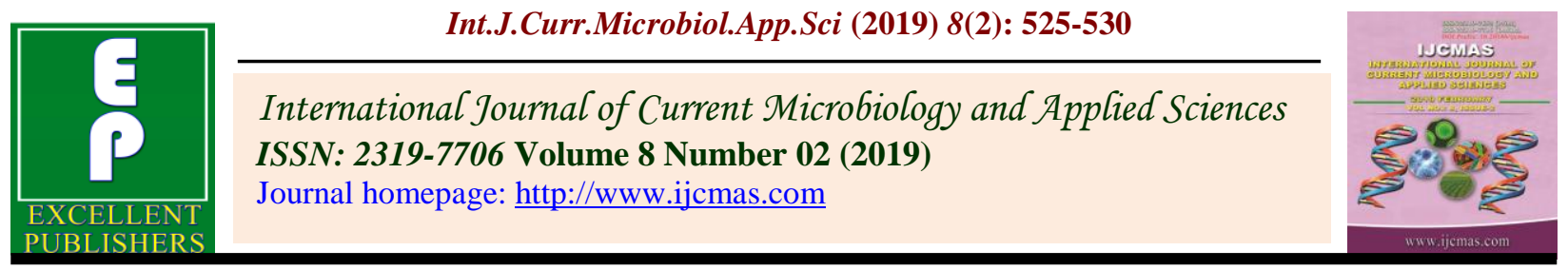

Original Research Article

https://doi.org/10.20546/ijcmas.2019.802.060

\title{
Economic Management and Analysis of Potato Cultivation: A case study of Agra district (U.P), India
}

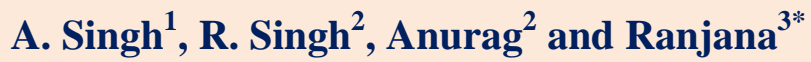 \\ ${ }^{1}$ Department of Agricultural Economics, College of Agriculture, RBS College, \\ Bichpuri, Agra, India \\ ${ }^{2}$ Department of Agricultural Economics, Sanskriti University, Mathura, India \\ ${ }^{3}$ Department of Agricultural Economics, Mangalayatan University, Aligarh, India \\ *Corresponding author
}

\begin{tabular}{|c|c|}
\hline & A B S T R A C T \\
\hline $\begin{array}{l}\text { Ke y w o r d s } \\
\text { Cost, Returns, } \\
\text { Potato, Agra, } \\
\text { Cultivation, } \\
\text { Output/input ratio }\end{array}$ & \multirow{3}{*}{$\begin{array}{l}\text { Economic study of potato production of } 44 \text { growers grouped into small (20), medium (14) } \\
\text { and large (10) from Agra district showed the overall cost of cultivation to be Rs. } 140303.7 \\
\text { per farm and Rs. } 78657.98 \text { per hectare. Among all the inputs, per hectare value of potato } \\
\text { seed was } 25 \% \text {, the human labour was } 14 \% \text {, the total variable cost was } 78 \% \text {, the total fixed } \\
\text { cost was } 22 \% \text { per ha and the overall total cost } C_{3} \text { of potato was Rs. } 154334.07 \text { per farm } \\
\text { and Rs. } 86523.78 \text { per hectare. The gross income received by farms with the overall } \\
\text { average of Rs. } 188370 \text {. The analysis of efficiency of potato production under different } \\
\text { categories of farms showed the overall cost of production of potato was Rs. } 292.3 \text { per } \\
\text { quintal. The overall output/input ratio was } 1: 2.39 \text {, being } 1: 3.42,1: 2.61 \text { and } 1: 2.21 \text { on the } \\
\text { small, medium and large farms, respectively. Thus, it could be concluded that with an } \\
\text { investment of one rupee in potato cultivation the small, medium and large farmers earned } \\
\text { Rs. } 3.42 \text {, Rs. } 2.61 \text { and Rs. } 2.21 \text {, respectively. }\end{array}$} \\
\hline Article Info & \\
\hline $\begin{array}{l}\text { Accepted: } \\
\text { 07 January } 2019 \\
\text { Available Online: } \\
10 \text { February } 2019\end{array}$ & \\
\hline
\end{tabular}

\section{Introduction}

India is the $2^{\text {nd }}$ largest Potato producer of the world, production $45.95 \mathrm{mt}$ during 2014-15 (Directorate of Economics and Statistics, 2016) and productivity 16-19 t/ha. In Uttar Pradesh, Agra as the major Potato market offers excellent opportunity for producing quality Potato of 58103 hectares from area of 15 development blocks with production of 1310700 tonnes (Dept. of Agriculture and Cooperation, Agra). The high value cash crops in the state is gaining momentum as it provides higher returns and promote value added agribusiness enterprises.

\section{Materials and Methods}

The present study is based on primary and secondary data information collected by the survey method of 44 Potato growers (20 small, 14 medium and 10 large farmers) of the Sonari village from the Bichpuri block. The final data was examined for resource endorsement and relationship between cost and returns of the Potato cultivation based on 
farm size groups, standard cost and income measurements to work out profitability of potato cultivation. The concepts used in costs and returns of potato cultivation were as follows.

\section{Cost concepts}

Cost $\mathrm{A}_{1}$ : Material cost + bullock/ tractor charges + interest over working capital. Cost $A_{2}$ : Cost $A_{1}+$ rent paid for leased land.

Cost B: Cost $\mathrm{A}_{2}+$ interest on the fixed capital + rental value of owned land.

Cost C: Cost $\mathrm{B}+$ imputed value of family Labour.

The interest on working capital at 12 per cent rate for half of the crop period and on fixed capital was computed as per prevailing lending rates.

\section{Farm efficiency measures}

Gross farm income (GFI): The gross value of output including by-product priced at farm harvest rates.

$\mathrm{GFI}=$ value of the main product + value of by product.

Net farm income (NFI): remuneration for the farmer's management

$\mathrm{NFI}=\mathrm{GFI}-\operatorname{Cost} \mathrm{C}_{2}$ (farm expenses)

Farm family labour income (FLI): Returns to family labour

$\mathrm{FLI}=\mathrm{GFI}-$ Cost $\mathrm{B}$.

Farm business income (FBI): return to labour, owned land, owned fixed capital and management.
$\mathrm{FBI}=\mathrm{GFI}-$ Cost $\mathrm{A}$

Farm investment income: The sum total of net farm income, interest on owned fixed capital and rental value of land.

\section{Results and Discussion}

\section{Cost of cultivation}

The computation of the cost of cultivation is necessary to determine the relative profitability of various crops over different crops. The detailed cost structure of the Potato cultivation (Table 1) shows overall per farm total cost of potato cultivation (Rs.140303.7) varies directly with the farm size. The percent share of seed cost to the total cost was as high as $30.2 \%$ on medium farms and as low as $27.54 \%$ on small farm size group. The total variable cost also varies with the farm size. The proportionate share of variable cost to the total cost was found lowest on the large farm size group and highest in the small farm size group.

Table 2 reveals that the per hectare items wise total cost of cultivation (Rs.78657.98) of potato. Among all the inputs, per hectare value of seeds of potato alone occupied about $25 \%$ to the total cost. Potato being labour intensive crop, human labour occupies $14 \%$ to the total cost that varies directly with farm size because of more hired labour employed on larger farms. The total variable cost accounted for $78 \%$ on overall farms, showing decreasing trends $(80,80$ and $83 \%$ to the total cost on the small, medium and large farm, respectively) with the farm size. The per hectare total fixed cost increases as the farm size increases and was found $22 \%$ to the total cost on overall farms. Expenditure on plant protection was about $2 \%$ of total cost clearly indicating the least risk taken for crop damage by insects. 
In nutshell, it can be concluded from the table that the potato growing farmers invest as much as they can depending upon the resources available to them.

\section{Costs and returns}

Table 3 indicates that per farm overall total cost $\mathrm{C}_{3}$ of potato was Rs.154334.07 and Rs.101846.22 per hectare. Per hectare gross income received by small, medium and large farms was Rs.174461.00, Rs.188209.00 and Rs.192395.00, respectively with an overall average of Rs.188370. Overall cost of production of potato was estimated Rs.292.30 per quintal being Rs.204.14, Rs.267.30 and Rs.316.44 on small, medium and large farms, respectively. Gross income, farm business income and family labour income and net income over cost $\mathrm{C}_{1}, \mathrm{C}_{2}$ and $\mathrm{C}_{3}$ vary directly with the farm size. The cost $C_{3}$ includes cost $\mathrm{C}_{2}$ and marginal cost, which is given to the farmer for managing the entire production process. All the costs in cost concept vary directly with the farm size. In all the cases cost $A_{1}$ and $A_{2}$ were the same because no case of lease-in land was found in the sample. The overall per hectare total cost $\mathrm{C}_{3}$ of potato came to the gross income received by Rs.174461 (small), Rs.188209 (medium) and Rs.192395 (large) farms with the overall average of Rs.188370.

Table.1 Per farm item-wise cost of cultivation (in Rs.)

\begin{tabular}{|l|l|l|l|l|l|l|l|l|}
\hline \multirow{2}{*}{ Item } & \multicolumn{3}{|l|}{ Small } & Medium & \multicolumn{3}{l|}{ Large } & \multicolumn{3}{l|}{ Overall } \\
\cline { 2 - 8 } & Value & $\%$ & Value & $\%$ & Value & $\%$ & Value & $\%$ \\
\hline Family Labour & 1521.34 & 2.79 & 2086.27 & 1.6 & 3134.07 & 1.04 & 1878.57 & 1.33 \\
\hline Casual & 5952.42 & 11.58 & 12465.11 & 9.56 & 31864.74 & 10.62 & 11424.9 & 8.14 \\
\hline Machine Labour & 9766.53 & 19 & 22014.24 & 16.89 & 33037.1 & 11 & 19851.7 & 14.14 \\
\hline Seed & 14157.14 & 27.54 & 39363.64 & 30.2 & 99680 & 33.21 & 42162.12 & 30.05 \\
\hline Fertilizer \& Manure & 8532.64 & 16.6 & 21831.82 & 16.75 & 38225.1 & 12.73 & 23921.42 & 17.04 \\
\hline Plant Protection & 716.63 & 1.39 & 1698.64 & 1.3 & 3575.25 & 1.19 & 2065.6 & 1.47 \\
\hline Operational Cost & 40646.09 & 79.08 & 99459.12 & 76.32 & 218547.2 & 72.81 & 101304.7 & 72.2 \\
\hline $\begin{array}{l}\text { Interest on Working } \\
\text { Capital }\end{array}$ & 1219.38 & 2.37 & 2983.78 & 2.28 & 6556.41 & 2.18 & 3039.14 & 2.16 \\
\hline Variable Cost & 41865.37 & 81.45 & 102442.9 & 78.61 & 225103.6 & 75 & 104343.8 & 74.33 \\
\hline $\begin{array}{l}\text { Depreciation on Fixed } \\
\text { Capital }\end{array}$ & 410.5 & 0.07 & 4132.4 & 3.17 & 12993.5 & 4.32 & 4635.54 & 3.3 \\
\hline $\begin{array}{l}\text { Interest on Fixed } \\
\text { Capital }\end{array}$ & 953.83 & 1.85 & 5270.1 & 4.04 & 14545.81 & 4.84 & 5628.55 & 4.01 \\
\hline Land Revenue & 45.42 & 0.08 & 150 & 0.11 & 350 & 0.11 & 275.72 & 0.19 \\
\hline Rental Value & 8120 & 15.79 & 18312 & 14.05 & 47140.5 & 1570 & 25420.1 & 18.11 \\
\hline Fixed Cost & 9529.75 & 18.54 & 27864.5 & 21.38 & 75029.81 & 24.99 & 35959.91 & 25.63 \\
\hline Total cost & 51395.12 & 100 & 130307.4 & 100 & 300133.4 & 100 & 140303.7 & 100 \\
\hline
\end{tabular}


Table.2 Per hectare item wise cost of cultivation (Rs.)

\begin{tabular}{|l|c|c|c|c|c|c|c|c|}
\hline \multirow{2}{*}{ Item } & \multicolumn{2}{|c|}{ Small } & \multicolumn{2}{c|}{ Medium } & \multicolumn{2}{c|}{ Large } & \multicolumn{2}{c|}{ Overall } \\
\cline { 2 - 9 } & Value & $\%$ & Value & $\%$ & Value & $\%$ & Value & $\%$ \\
\hline Family Labour & 1673.65 & 3.28 & 2198.38 & 3.05 & 2459 & 2.82 & 1991.76 & 2.53 \\
\hline Casual & 5462.8 & 10.73 & 8656.22 & 12.04 & 11331.65 & 13.02 & 9507.99 & 12.08 \\
\hline Machine Labour & 8961.21 & 17.6 & 10971 & 15.26 & 13471.14 & 15.48 & 11430.61 & 14.53 \\
\hline Seed & 14877.6 & 29.23 & 18962.12 & 23.6 & 22000 & 25.3 & 19000 & 24.15 \\
\hline $\begin{array}{l}\text { Fertilizer } \\
\text { Manure }\end{array}$ & 8000 & 15.71 & 14000.12 & 19.48 & 17936 & 20.62 & 16000 & 20.34 \\
\hline Plant Protection & 550.8 & 1.08 & 1180.2 & 1.61 & 1560.12 & 1.79 & 1301.42 & 1.65 \\
\hline Operational Cost & 39526.26 & 77.66 & 55967.78 & 77.87 & 70068.13 & 80.56 & 59581.9 & 75.75 \\
\hline $\begin{array}{l}\text { Interest on } \\
\text { Working Capital }\end{array}$ & 1185.78 & 2.32 & 1679.03 & 2.75 & 2102.04 & 2.41 & 1787.45 & 2.27 \\
\hline Variable cost & 40711.84 & 79.99 & 57646.81 & 80.21 & 72170.17 & 82.97 & 61369.36 & 78.02 \\
\hline $\begin{array}{l}\text { Depreciation on } \\
\text { Fixed Capital }\end{array}$ & 390.18 & 0.76 & 2402.2 & 3.34 & 2752.1 & 3.16 & 2210.8 & 2.81 \\
\hline $\begin{array}{l}\text { Interest on Fixed } \\
\text { Capital }\end{array}$ & 880.12 & 1.72 & 2787.12 & 3.87 & 2987.1 & 3.43 & 2773.71 & 3.53 \\
\hline Land Revenue & 40 & 0.07 & 42.4 & 0.05 & 66.77 & 0.07 & 304.11 & 0.39 \\
\hline Rental Value & 8870 & 17.42 & 8990 & 12.5 & 9000 & 10.34 & 12000 & 15.25 \\
\hline Fixed Cost & 10180.3 & 20 & 14221.72 & 19.78 & 14805.97 & 17.02 & 17288.62 & 21.98 \\
\hline Total Cost & 50892.14 & 100 & 71868.53 & 100 & 86976.14 & 100 & 78657.98 & 100 \\
\hline
\end{tabular}

Table.3 Cost of cultivation (in Rs.)

\begin{tabular}{|l|c|c|c|c|c|c|c|c|}
\hline & \multicolumn{3}{|c|}{ Per Farm Cost Concept } & \multicolumn{3}{c|}{ Per Hectare Cost Concept } \\
\hline $\begin{array}{l}\text { Cost } \\
\text { Concept }\end{array}$ & Small & Medium & Large & Overall & Small & Medium & Large & Overall \\
\hline Cost $\mathbf{A}_{\mathbf{1}}$ & 40800 & 104639 & 235313 & 107376 & 39468.4 & 57893 & 72530 & 61892.5 \\
\hline Cost $\mathbf{A}_{\mathbf{2}}$ & 40800 & 104639 & 235313 & 107376 & 39468.4 & 57863 & 72530 & 61892.5 \\
\hline Cost $\mathbf{B}_{\mathbf{1}}$ & 41753.8 & 109909 & 249859 & 113005 & 40348.5 & 60680.2 & 75517.1 & 64666.2 \\
\hline Cost $\mathbf{B}_{\mathbf{2}}$ & 49873.8 & 128221 & 296999 & 138425 & 49218.5 & 69670.2 & 84517.1 & 76666.2 \\
\hline Cost d & 43275.1 & 111995 & 252993 & 114884 & 42022.1 & 62878.5 & 77976.1 & 66658 \\
\hline Cost $\mathbf{C}_{\mathbf{2}}$ & 51395.1 & 130307 & 300133 & 140304 & 50892.1 & 71868.5 & 86976.1 & 78658 \\
\hline Cost $\mathbf{C}_{\mathbf{3}}$ & 56534.6 & 143338 & 330147 & 154334 & 55981.4 & 79055.4 & 95673.8 & 86523.8 \\
\hline
\end{tabular}


Table.4 Farm business analysis (in Rs.)

\begin{tabular}{|c|c|c|c|c|c|c|c|c|}
\hline \multirow{2}{*}{$\begin{array}{l}\text { Income } \\
\text { concept } \\
\text { Gross } \\
\text { Income }\end{array}$} & \multicolumn{4}{|c|}{ Per Farm } & \multicolumn{4}{|c|}{ Per Hectare } \\
\hline & Small & Medium & Large & Overall & Small & Medium & Large & Overall \\
\hline $\begin{array}{l}\text { Farm } \\
\text { Business } \\
\text { Income }\end{array}$ & 178003 & 487452 & 1285704 & 550032 & 174461.00 & 188209 & 192395 & 188370 \\
\hline $\begin{array}{l}\text { Family } \\
\text { Labour } \\
\text { Income }\end{array}$ & 137203.05 & 383812.97 & 1050390.98 & 395697.93 & 134992.63 & 130316 & 119875 & 126477 \\
\hline $\begin{array}{l}\text { Net Income } \\
\text { Over } C_{1}\end{array}$ & 128129.22 & 359230.87 & 988704.67 & 411606.87 & 125242.51 & 118539 & 107878 & 111704 \\
\hline $\begin{array}{l}\text { Net Income } \\
\text { Over } \mathrm{C}_{2}\end{array}$ & 137727.88 & 375456.6 & 1032711.1 & 435148.4 & 132438.86 & 125330 & 844419 & 121712 \\
\hline $\begin{array}{l}\text { Net Income } \\
\text { Over } C_{3}\end{array}$ & 126607.88 & 344114.15 & 985570.6 & 409728.3 & 123568.86 & 116340 & 105419 & 109712 \\
\hline $\begin{array}{l}\text { Farm } \\
\text { investment } \\
\text { Income }\end{array}$ & 121468.37 & 380726.70 & 95557.26 & 395697.93 & 118479.65 & 109154 & 96721.3 & 101846 \\
\hline $\begin{array}{l}\text { Cost of } \\
\text { Production }\end{array}$ & 135681.71 & 187.12 & 1047256.91 & 393819.36 & 133318.98 & 128118 & 117415 & 124486 \\
\hline $\begin{array}{l}\text { Output- } \\
\text { input Ratio }\end{array}$ & 202.11 & 169.09 & 163.4 & 178.55 & 204.14 & 267.3 & $316 . .44$ & 292.3 \\
\hline $\begin{array}{l}\text { Gross } \\
\text { Income }\end{array}$ & 3.46 & 3.74 & 4.28 & 3.89 & 3.42 & 2.61 & 2.21 & 2.39 \\
\hline
\end{tabular}

Analysis of costs and returns is of vital importance both the point of view of evolving sound production plans and for the formulation of price policy. The costs and returns study of a particular crop enterprise also provides very useful information for improving the farm efficiency.

\section{Farm efficiency}

Table 4 reveals that the overall cost of production of potato was Rs.292.3 per quintal being Rs.204.14, Rs.267.3 and Rs.316.44 on small, medium and large farms, respectively. Net income over cost $C_{2}$ and $C_{3}$ was less than net income over cost $\mathrm{C}_{1}$ in case of all the sample farmers, which indicates that the farm family members were not getting their dues share as laborers and manage Rs. So far as family labour income and farm business income are concerned potato provides positive returns to the farmers of all farm size groups. The output/input ratio was 1:2.39, being $1: 3.42,1: 2.61$ and $1: 2.21$ on small, medium and large farms, respectively.

Based on the above study it can be concluded that with the investment of one rupee in potato cultivation small, medium and large farmers earned Rs.3.42, Rs.2.61 and Rs.2.21, respectively.

\section{Acknowledgement}

The author is highly thankful to R.B.S College, Bichpuri, Sanskriti University, 
Mathura and Mangalayatan University for providing necessary support to conduct the research.

\section{References}

Sharma, B., and Tripathi, B.N., 2005. Economics of potato cultivation in Allahabad district of Uttar Pradesh. New Agriculturist 16: 75-79

Sinha, R.P., Singh, U.K. 1996. Economic analysis of potato cultivation: a case study of Nalanda district (Bihar).
Journal of Applied Biology 6(1/2): 121-123

Tripathi, R.S., 1991. Economics of potato cultivation in the high hills of Uttar Pradesh. Journal of the Indian Potato Association 18: 142-146.

Vikalp Sharma, Harbans Lal, Utpalendu Debnath and Vinay Hatte. 2017. Economics of Potato Production in Kangra District of Himachal Pradesh, India. Int.J.Curr.Microbiol.App.Sci. 6(10): 123-129.

\section{How to cite this article:}

Singh, A., R. Singh, Anurag and Ranjana. 2019. Economic Management and Analysis of Potato Cultivation: A case study of Agra district (U.P). Int.J.Curr.Microbiol.App.Sci. 8(02): 525-530. doi: https://doi.org/10.20546/ijcmas.2019.802.060 